\title{
Iron and zinc retention in common beans (Phaseolus vulgaris L.) after home cooking
}

\author{
Lucia M. J. Carvalho'*, Mariana M. Corrêal, Elenilda J. Pereira', \\ Marília R. Nutti², José L. V. Carvalho², Ediane M. G. Ribeiro' and \\ Sidinéa C. Freitas ${ }^{2}$
}

'Pharmacy College, Universidade Federal do Rio de Janeiro, Ilha do Fundão, Rio de Janeiro, Brazil; ${ }^{2}$ Embrapa Food Technology, Rio de Janeiro, Brazil

\section{Abstract}

Background: According to the World Health Organization (WHO), iron, iodine, and Vitamin A deficiencies are the most common forms of malnutrition, leading to severe public health consequences. The importance of iron and zinc in human nutrition and the number of children found to be deficient in these nutrients make further studies on retention in cooked grains and cooked bean broth important.

Objectives: This work aimed to evaluate iron and zinc retention in six common bean (Phaseolus vulgaris L.) cultivars under the following conditions: raw beans, regular pot cooking, pressure cooking, with and without previous water soaking, and broth.

Design: Determination of iron and zinc content in the raw, cooked bean grains and broth samples was carried out by Inductively Coupled Plasma (ICP) Optical Emission Spectrometry (Spectro Analytical Instrument - Spectroflame P). All experiments and analyses were carried out in triplicate.

Results: Overall, regardless of the cooking method, with or without previous water soaking, the highest zinc concentration was found in the cooked bean grains. However, pressure cooking and previous water soaking diminished iron retention in the cooked grains, while increasing it in the bean broth.

Conclusion: The common bean was confirmed to be an excellent source of iron and zinc for human consumption, and it was suggested that beans should be consumed in a combined form, i.e. grain with bean broth.

Keywords: leguminosae; mineral deficiencies; cooking methods; micronutrients; food analysis; food composition; common beans

Received: 8 December 2011; Revised: 6 January 2012; Accepted: 26 January 20I2; Published: 29 February 2012

A ccording to the World Health Organization (WHO), iron, iodine, and Vitamin A deficiencies are the most common forms of malnutrition, leading to severe public health consequences. Iron and zinc deficiencies can cause anemia, compromising physical work capacity, and leading to growth retardation and alterations in neurological function and immunological response (1-4). Such deficiencies are in general caused by the lack of financial means to acquire and consume red meat, chicken, fish, fruit, and vegetables in the amounts required $(5,6)$.

Leguminous grains play an important role in human nutrition, being one of the main foods in the standard diet of low-income people in developing countries.
The common bean (Phaseolus vulgaris L.) contains essential minerals, such as iron, zinc, calcium, and phosphorus. Normally, its iron and zinc contents range from $18.8-82.4 \mathrm{mg}$ of $\mathrm{Fe} / \mathrm{g}$ and from 32.6 to $70.2 \mathrm{mg}$ of $\mathrm{Zn} / \mathrm{kg}(7,8)$.

However, these levels may vary in function depending on various factors: species; variety; processing factors, such as storage time, temperature, and food preparation (9).

Several types of bean grains are commercialized in the Brazilian market, with 'carioca' (red beans) being currently the most consumed. However, the small and opaque bean seeds (black beans) are more popular in southern and eastern Paraná, Rio de Janeiro, southeastern Minas Gerais, and southern Espírito Santo. 
The majority of the adult population consumes cooked bean grains combined with bean broth. In Brazil, the broth is consumed as an appetizer drink. However, studies on standard food consumption of infants ( $0-5$ years old) - one of the main groups presenting with risk of nutritional deficiencies - have revealed that infants are fed exclusively bean broth diet. Current dietary recommendations for children weaned are important because this is the period in which eating habits are established and continue into adolescence and adulthood (10-12).

In view of the high bean consumption in Brazil and in other developed and developing countries, the importance of iron and zinc in human nutrition, and the number of children deficient in these nutrients, further studies must be carried out on retention of these minerals in the cooked grains and cooked bean broth.

This work aimed to evaluate iron and zinc retention in six common bean cultivars (Phaseolus vulgaris L.) under the following conditions: raw beans, regular pot cooking, pressure cooking, with and without previous water soaking, and broth.

\section{Materials and methods}

\section{Raw material}

Six common bean (Phaseolus vulgaris L.) cultivars samples, BRS Pontal (beige); BRS Grafite (black); BRS Marfim (brown); Jalo Precoce (beige); BRS Radiante (beige), and BRS Vereda (beige), were cultivated and provided by Embrapa Rice and Beans, Santo Antônio de Goiás, GO.

\section{Home cooking methods}

The grains of six common bean cultivars were submitted to four different cooking methods (Fig. 1): (1) regular pot cooking without previous soaking (WPSCP); (2) regular pot cooking with previous water soaking (SCP); (3) pressure cooking without previous water soaking (WSPP); and (4) pressure cooking with previous water soaking (SPP) during previously determined cooking times using the Burr Experimental Cooker. The cooking time method determination was done according to the same methodology adopted by Burr and Morris (1968), the time was determined by an experimental laboratory cooker (JAB-77) 'minor type' with 25 pin, weighing

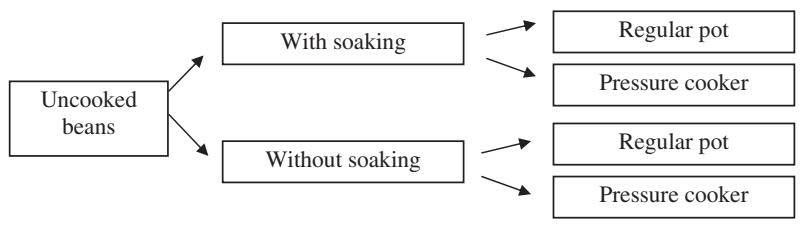

Fig. 1. Common bean home cooking methods used.
$90 \mathrm{~g}$ each, manufactured in Jaboticabal - SP. The cooking time was determined after the 13th pin fell down.

Sample size was $100 \mathrm{~g}$ of beans cooked in $1,000 \mathrm{ml}$ water (1:10). All experiments were carried out in triplicate.

Previous bean soaking in water was performed over $16 \mathrm{~h}$ (overnight) in a glass beaker at room temperature. The grains were cooked in the deionized soaking water.

The pots and lids were washed in water, immersed in a 5\% nitric acid solution over $1 \mathrm{~h}$, and rinsed with ultra-pure water (Mili-Q, Millipore, Milford, USA) before being submitted to the different cooking methods.

Regular pot cooking was carried out with the lid half open; $500 \mathrm{ml}$ of water was added during cooking to correct the loss of water by evaporation during cooking. No water replacement was necessary in pressure cooking.

\section{Preparation of the samples for iron and zinc analysis}

All the material was previously decontaminated in a nitric acid solution $\left(\mathrm{HNO}_{3}-1: 1\right)$, prepared with distilled water. The raw bean samples were selected manually before being polished with flannel cloth for $5 \mathrm{~min}$ and kept in clean glass receptacles.

The polished bean grains were washed with deionized water (Mili-Q, Millipore, Milford, USA) and hand crushed. After washing, all the water was discarded. Grain drying was performed in an oven at $60{ }^{\circ} \mathrm{C}$, with no air circulation, overnight.

The raw grains of each cultivar were grounded in a zirconium ball mill (RETSCH model MM200, Retsch Gmbtt \& Co. KG. Haan, Germany), until a sufficient amount was obtained for analysis.

The grounded raw bean samples were divided into three aliquots of $0.2 \mathrm{~g}$ and placed in assay tubes.

The broth in the cooked bean samples was completely drained through a plastic sieve into a beaker (previously weighed), and the bean grains were transferred into another glass receptacle, with three aliquots of $0.8 \mathrm{~g}$ of cooked grains and $2.0 \mathrm{~g}$ of broth being transferred into assay tubes.

Sample digestion was carried out by acid hydrolysis, through the addition of $2 \mathrm{ml}$ of a nitric perchloric acid solution $(2: 1)$ for approximately $16 \mathrm{~h}$ at room temperature. After oxidation, the samples were heated in a digestion block (Technal, São Paulo, Brazil), in a fume hood at a slow boil to $100{ }^{\circ} \mathrm{C}\left( \pm 2{ }^{\circ} \mathrm{C}\right)$ over $1 \mathrm{~h}$ and maintained for an additional $2 \mathrm{~h}$ at $170{ }^{\circ} \mathrm{C}\left( \pm 2{ }^{\circ} \mathrm{C}\right)$. After the samples were cooled at room temperature, $2 \mathrm{ml}$ of the nitric perchloric solution were added to each tube, which were returned to the digestion block for another $4 \mathrm{~h}$ at $170{ }^{\circ} \mathrm{C}\left( \pm 2{ }^{\circ} \mathrm{C}\right)(13,14)$.

The tubes were removed from the digestion block and the samples were transferred into a volumetric flask $(25 \mathrm{ml})$ and the volume completed with ultra-pure water (Milli-Q, Millipore, Milford, USA). 


\section{Iron and zinc analysis}

Determination of iron and zinc content in the raw, cooked bean grains and broth samples was carried out by Inductively Coupled Plasma (ICP) Optical Emission Spectrometry (Spectro Analytical Instrument - Spectroflame P). Micronutrient concentrations were calculated based on calibration curves with iron and zinc standard solutions $(0.25,0.5,1.0$, and $1.5 \mathrm{mg} / \mathrm{kg})(14)$. All analyses were carried out in triplicate and the results were thus calculated:

$($ ICP mineral emission $) \times($ dilution factor $) /$

$($ aliquot weight $)=($ sample mineral content $-\mathrm{mg} / \mathrm{kg})$

(sample mineral content $-\mathrm{mg} / \mathrm{kg}) / 10$

$=($ sample mineral content $-\mathrm{mg} / 100 \mathrm{~g})$

(sample mineral content $-\mathrm{mg} / 100 \mathrm{~g}) \times$

$100 /$ (sample dry weight)

$=($ mineral dry basis content $-\mathrm{mg} / 100 \mathrm{~g})$

\section{Moisture analysis}

Determination of bean grain moisture was carried out by the gravimetric method according to a methodology developed by the Instituto Adolfo Lutz (15).

\section{Statistical analysis}

The statistical analyses were carried out using the GraphPad Prism Software Version 4. Descriptive methods and $t$ test analysis were applied. Descriptive analysis was used to characterize the samples studied. For each mineral, differences between the bean broth and bean grain results in the samples, with and without previous water soaking, were evaluated by the paired $t$ test. The differences between the bean broth and bean grain in the pressure cooker and regular pot samples were evaluated by the non-paired $t$ test.

\section{Results}

The cooking times of common bean cultivars using the Burr cooker, with and without previous soaking in water, is shown in Table 1.

The Jalo Precoce variety needed the highest cooking time (without previous soaking in water) and the BRS Pontal the lowest. However, when cooked after soaking, the BRS Radiante had the highest cooking time and the BRS Grafite the lowest one.

Table 2 shows the iron and zinc contents in the raw bean grains. The cultivar BRS Marfim had the highest iron content $(74.7 \mathrm{mg} / \mathrm{kg}$ ) followed by the cultivars BRS Grafite $(69.5 \mathrm{mg} / \mathrm{kg})$ and BRS Vereda $(68.8 \mathrm{mg} / \mathrm{kg})$.

The cultivars analyzed presented zinc contents ranging from $33.8 \mathrm{mg} / \mathrm{kg}$ (Jalo Precoce) to $43.1 \mathrm{mg} / \mathrm{kg}$ (BRS Grafite).
Table 1. Cooking times of common bean cultivars using the Burr cooker, with and without previous soaking in water

\begin{tabular}{lcc}
\hline & \multicolumn{2}{c}{ Cooking time (min) } \\
\cline { 2 - 3 } Cultivar & Without soaking & With soaking \\
\hline BRS Vereda & $52.18^{\mathrm{ab}}$ & $14.31^{\mathrm{bc}}$ \\
BRS Grafite & $49.98^{\mathrm{ab}}$ & $13.81^{\mathrm{bc}}$ \\
BRS Radiante & $59.18^{\mathrm{ab}}$ & $19.75^{\mathrm{a}}$ \\
BRS Pontal & $46.95^{\mathrm{b}}$ & $15.08^{\mathrm{bc}}$ \\
BRS Marfim & $53.37^{\mathrm{ab}}$ & $14.33^{\mathrm{bc}}$ \\
Jalo Precoce & $67.50^{\mathrm{a}}$ & $16.55^{\mathrm{b}}$ \\
\hline
\end{tabular}

Different letters in the same column differ significantly at $5 \%$ probability

The highest iron content was found in BRS Pontal $(54.9 \mathrm{mg} / \mathrm{kg})$ in the beans pressure-cooked with previous soaking and without soaking in the BRS Vereda cultivar $(56.8 \mathrm{mg} / \mathrm{kg})$. Considering the contents of the broth, the total iron contents in both were 62.3 and $70.0 \mathrm{mg} / \mathrm{kg}$, respectively (Table 3 ).

The iron contents in the beans cooked with and without previous soaking in a regular pot were highest in the BRS Marfim cultivar, 74.4 and $70.4 \mathrm{mg} / \mathrm{kg}$, respectively. The total iron contents for both cooking methods using a regular pot, considering the content in the broth, were 75.3 (BRS Marfim) and $74.8 \mathrm{mg} / \mathrm{kg}$, respectively.

A significant difference was found in the iron contents, both in the cooked bean grains and bean broth, with and without previous water soaking and pressure-cooked, compared to those cooked in a regular pot. In addition, the iron content in the bean grains previously soaked in water and in those without water soaking was significantly different (Table 3 ).

The zinc contents were highest in the BRS Grafite (36.1 and $38.8 \mathrm{mg} / \mathrm{kg}$ ) cooked under pressure with and without previous soaking (Table 4). The total zinc contents in both pressure cooking methods, considering the content in the broth, were 43.0 and $43.1 \mathrm{mg} / \mathrm{kg}$, respectively, in the BRS Grafite cultivar.

The zinc contents were $36.2 \mathrm{mg} / \mathrm{kg}$ (BRS Pontal) and $38.5 \mathrm{mg} / \mathrm{kg}$ after being cooked in a regular pot, with and without soaking, respectively. Considering the beans

Table 2. Iron and zinc content ( $\mathrm{mg} / \mathrm{kg}$ dry matter) in raw beans ${ }^{1}$

\begin{tabular}{lll}
\hline Cultivars & Fe $(\mathrm{mg} / \mathrm{kg})^{2}$ & $\mathrm{Zn}(\mathrm{mg} / \mathrm{kg})^{2}$ \\
\hline BRS Vereda & $68.8( \pm 0.30)$ & $39.4( \pm 0.40)$ \\
BRS Grafite & $69.5( \pm 0.39)$ & $43.1( \pm 0.25)$ \\
BRS Radiante & $53.1( \pm \mathrm{I} .08)$ & $33.5( \pm 0.48)$ \\
BRS Pontal & $62.3( \pm \mathrm{I} .91)$ & $42.7( \pm 0.66)$ \\
BRS Marfim & $74.7( \pm 0.95)$ & $39.1( \pm 1.01)$ \\
Jalo Precoce & $55.8( \pm 0.60)$ & $33.8( \pm 0.53)$ \\
\hline
\end{tabular}

Mean and standard deviation; I, Dried overnight; 2, Dry basis. 
Table 3. Iron content (mg/kg dry matter) in home cooked beans and bean broth

\begin{tabular}{|c|c|c|c|c|c|c|c|c|}
\hline \multirow[b]{3}{*}{ Iron (mg/kg) } & \multicolumn{4}{|c|}{ Pressure cooking } & \multicolumn{4}{|c|}{ Regular pot } \\
\hline & \multicolumn{2}{|c|}{ With soaking (SPP) } & \multicolumn{2}{|c|}{ Without soaking (WSPP) } & \multicolumn{2}{|c|}{ With soaking (SCP) } & \multicolumn{2}{|c|}{ Without soaking (WPSCP) } \\
\hline & Beans & Broth & Beans & Broth & Beans & Broth & Beans & Broth \\
\hline BRS Vereda & $48.4( \pm 3.1)^{c}$ & $24.8( \pm 3.1)^{\mathrm{c}}$ & $56.8( \pm 0.8)$ & $13.2( \pm 0.8)$ & $51.5( \pm 2.5)^{\mathrm{a}}$ & $17.3( \pm 2.5)^{\mathrm{a}}$ & $56.4( \pm 4.5)^{\mathrm{b}, \mathrm{d}}$ & $12.4( \pm 6.4)^{\mathrm{b}}$ \\
\hline BRS Grafite & $49.5( \pm 0.5)^{c}$ & $19.9( \pm 0.5)^{c}$ & $54.0( \pm 0.7)$ & $15.5( \pm 0.7)$ & $60.9( \pm 3.4)^{\mathrm{a}}$ & $8.5( \pm 3.4)^{\mathrm{a}}$ & $61.9( \pm 2.0)^{\mathrm{b}}$ & $7.6( \pm 2.0)^{b}$ \\
\hline BRS Radiante & $42.8( \pm 0.9)^{c}$ & $10.3( \pm 0.9)^{c}$ & $51.3( \pm 0.1)$ & $1.8( \pm 0.1)$ & $39.2( \pm 1.7)^{\mathrm{a}}$ & $13.9( \pm 1.7)^{\mathrm{a}}$ & $41.6( \pm 2.5)^{\mathrm{b}}$ & $11.5( \pm 2.5)^{\mathrm{b}}$ \\
\hline BRS Pontal & $54.9( \pm 2.3)$ & $7.4( \pm 2.3)$ & $54.0( \pm 0.2)$ & $8.3( \pm 0.2)$ & $50.6( \pm 2.7)$ & II.7 ( \pm 2.7$)$ & $55.3( \pm 1.7)^{\mathrm{d}}$ & $6.9( \pm 1.7)$ \\
\hline BRS Marfim & $49.6( \pm 0.3)^{c}$ & $33.6( \pm 0.3)^{c}$ & $47.4( \pm 0.7)$ & $36.2( \pm 0.7)$ & $74.4( \pm 0.4)^{\mathrm{a}}$ & $0.9( \pm 0.4)^{\mathrm{a}}$ & $70.4( \pm 0.4)^{\mathrm{b}, \mathrm{d}}$ & $4.4( \pm 0.4)^{b}$ \\
\hline Jalo Precoce & $41.2( \pm 3.1)^{c}$ & $15.4( \pm 3.1)^{c}$ & $46.9( \pm 4.3)$ & $9.6( \pm 4.3)$ & $38.0( \pm 2.0)$ & $18.6( \pm 2.0)$ & $50.5( \pm 0.1)^{\mathrm{b}, \mathrm{d}}$ & $6.1( \pm 0.1)^{b}$ \\
\hline
\end{tabular}

Mean and standard deviation: I - dry basis results.

SPP, with previous soaking in water and pressure cooked; WSPP, without soaking in water and pressure cooked; SCP, with previous soaking in water and cooked in a regular pot; WPSCP, without previous soaking in water and cooked in a regular pot.

${ }^{a}$ Significantly different from SPP.

bSignificantly different from WSPP.

'Significantly different from WSPP.

${ }^{d}$ Significantly different from WPSCP (unpaired $t$ test).

and broth together, the total zinc contents were 42.7 (BRS Pontal) and $43.1 \mathrm{mg} / \mathrm{kg}$, respectively.

Table 4 shows the zinc contents in cooked grain and in the broth of common bean cultivars after different cooking methods, with no significant differences being found between the two types of cooking (regular pot and pressure cooker). However, previous soaking in water was found to influence the zinc contents in the cooked grains of the cultivars BRS Grafite, BRS Radiante, and BRS Pontal.

\section{Discussion}

According to Coelho et al. (16), cooking time depends mainly on the cultivar studied and the soaking time. They found different results in cooking times with the BRS Valente cultivar previously soaked in deionized water for $6 \mathrm{~h}(23-30 \mathrm{~min})$ in contrast to our results which showed that cooking times after soaking varied from 13.81 (BRS Grafite) to $19.75 \mathrm{~min}$ (BRS Radiante).

The cultivars analyzed presented iron contents ranging from 74.7 (BRS Marfim) to $53.1 \mathrm{mg} / \mathrm{kg}$ (BRS Radiante). However, the cultivars analyzed presented zinc contents ranging from $33.8 \mathrm{mg} / \mathrm{kg}$ (Jalo Precoce) to $43.1 \mathrm{mg} / \mathrm{kg}$ (BRS Grafite), which are higher than those found in a study by Ribeiro et al. (17), who demonstrated iron contents of $71.54 \mathrm{mg} / \mathrm{kg}$ and zinc of $30.05 \mathrm{mg} / \mathrm{kg}$ as well as by Beebe et al. (18) in bean cultivars grown in Colombia.

The tendency toward higher zinc content in cooked beans may be due to the fact that soaking is more effective in increasing the extractability of trace elements like copper, zinc, and manganese, while fermenta-

Table 4. Zinc content ( $\mathrm{mg} / \mathrm{Kg}$ dry matter) in cooked beans and bean broth

\begin{tabular}{|c|c|c|c|c|c|c|c|c|}
\hline \multirow[b]{3}{*}{ Zinco (mg/kg) } & \multicolumn{4}{|c|}{ Pressure cooking } & \multicolumn{4}{|c|}{ Regular pot } \\
\hline & \multicolumn{2}{|c|}{ With soaking (SPP) } & \multicolumn{2}{|c|}{ Without soaking (WSPP) } & \multicolumn{2}{|c|}{ With soaking (SCP) } & \multicolumn{2}{|c|}{ Without soaking (WPSCP) } \\
\hline & beans & Broth & beans & broth & beans & broth & beans & Broth \\
\hline BRS Vereda & $30.9( \pm 0.3)$ & $8.4( \pm 0.3)$ & $30.6( \pm 2.3)$ & $8.8( \pm 2.3)$ & $28.4( \pm 1.4)$ & $9.8( \pm 1.4)$ & $29.8( \pm 1.3)$ & $9.6( \pm 1.3)$ \\
\hline BRS Grafite & $36.1( \pm 1.2)$ & $6.9( \pm 1.2)$ & $38.8( \pm 0.3)$ & $4.3( \pm 0.3)^{\mathrm{a}}$ & $34.4( \pm 1.1)$ & $8.7( \pm 1.1)$ & $38.5( \pm 0.9)$ & $4.6( \pm 0.9)^{b}$ \\
\hline BRS Radiante & $25.3( \pm 0.8)$ & $8.2( \pm 0.8)$ & $32.8( \pm 0.3)$ & $0.8( \pm 0.3)^{\mathrm{a}}$ & $28.1( \pm 2.6)$ & $5.4( \pm 2.6)$ & $26.2( \pm 2.0)$ & $7.4( \pm 2.0)^{\mathrm{b}}$ \\
\hline BRS Pontal & $26.6( \pm 1.9)$ & $16.1( \pm 1.9)$ & $32.7( \pm 0.6)$ & $9.9( \pm 0.6)^{\mathrm{a}}$ & $36.2( \pm 1.2)$ & $6.5( \pm 1.2)$ & $31.8( \pm 0.9)$ & $10.9( \pm 0.9)^{\mathrm{b}}$ \\
\hline BRS Marfim & $31.8( \pm 0.1)$ & $7.9( \pm 0.1)$ & $37.5( \pm 0.1)$ & $2.6( \pm 0.1)$ & $30.8( \pm 0.5)$ & $9.8( \pm 0.5)$ & $37.7( \pm 0.2)$ & $2.7( \pm 0.2)$ \\
\hline Jalo Precoce & $26.5( \pm 2.5)$ & $7.3( \pm 2.5)$ & $27.2( \pm 2.0)$ & $6.6( \pm 2.0)$ & $27.9( \pm 0.6)$ & $5.9( \pm 0.6)$ & $27.6( \pm 2.2)$ & $6.2( \pm 2.2)$ \\
\hline
\end{tabular}

Mean and standard deviation. ${ }^{a}$ Significantly different from SPP; ${ }^{b}$ significantly different from WPSCP (- unpaired $t$ test). SPP - with previous immersion in water and pressure cooked; WSPP - without immersion in water and pressure cooked; SCP - with previous immersion in water and cooked in a regular pot; WPSCP - without previous immersion in water and cooked in a regular pot. 
tion can be more effective in increasing the iron extractability (19).

The values reported in the Brazilian Food Composition Table for iron and zinc in Phaseolus vulgaris ranged from 11 to $19 \mathrm{mg} / \mathrm{kg}$, and 7 to $13 \mathrm{mg} / \mathrm{kg}$ in cooked samples, respectively. However, values are significantly higher in raw bean samples varying from 51 to $186 \mathrm{mg} / \mathrm{kg}$ for iron and 26 to $40 \mathrm{mg} / \mathrm{kg}$, for zinc (20). It must be emphasized that in the results reported by RamirezCárdenas et al. (21) the grain values and the bean broth analyzed were considered as a single sample.

A food can be labeled as the 'source' of a nutrient when $100 \mathrm{~g}$ of the product presents more than $15 \%$ of the dietary reference intake (DRI) for the desired nutrient. For example, 15\% DRI is equivalent to 21 $\mathrm{mg} / \mathrm{Kg}$ of the product $(2.1 \mathrm{mg} / 100 \mathrm{~g})$ and zinc $22.5 \mathrm{mg} /$ $\mathrm{Kg}(2.25 \mathrm{mg} / 100 \mathrm{~g})$ is considered as a source, and contains $42 \mu \mathrm{g}$ of iron/g of the product and $45 \mathrm{mg} / \mathrm{Kg}$ for zinc when considered high. Similarly, when the food contains at least double the amount determined as a 'source', it can be labeled 'high'. The DRI value recommended for iron is $14 \mathrm{mg} /$ day and for zinc $15 \mathrm{mg} /$ day (22).

In view of the iron and zinc deficiencies and high values found in some of the cultivars analyzed by Mechi et al. (23), black common bean cultivation and consumption can be indicated to meet these deficiencies in low-income populations of underdeveloped and developing countries, mainly in infants and pregnant women.

Overall, regardless of the type of home cooking method, with or without water soaking, the highest zinc concentration was found in the cooked bean grain (BRS Grafite with and without previous soaking cooked under pressure). However, pressure cooking and previous water soaking influenced iron and zinc retention in the cooked bean grain, complementing the concentration of this nutrient in the bean broth.

According to Mechi et al. (23) iron contents ranging from 98 to $126.3 \mathrm{mg} / \mathrm{kg}$ were found in black beans ( $P$. vulgaris L.) raw and cooked, respectively (in dry basis). The USDA reported contents of 56.42 and $61.30 \mathrm{mg} / \mathrm{kg}$ for raw and cooked beans, respectively (24). However, another value was reported by FAO $(93 \mathrm{mg} / \mathrm{kg})$ in raw black beans (25).

Thus, the common bean was confirmed to be an excellent source of iron and zinc for human consumption since phytic acid is reduced after processes such as soaking, germination, and heat, promoting an increase in mineral extractability and bioavailability. The presence of phytates and tannins in vegetable fibers can negatively influence the bioavailability of zinc and iron as well as the cooking of the grain. However, the tannins have no significant influence on the bioavailability of zinc and iron from cereals and legumes (26).
Considering that the majority of the population is iron deficient worldwide, the high content found in the studied cultivars, mainly in BRS Pontal, confirms the fact that the common bean can be considered a good source of iron as well as of zinc, and help fight anemia in low-income populations of underdeveloped and developing countries, especially in infants and pregnant women.

\section{Acknowledgements}

We thank the HarvestPlus Program for the financial support; Embrapa Food Technology, for allowing the use of its equipments and facilities; and Embrapa Rice and Beans for providing the cultivar samples.

\section{Conflict of interest and funding}

The HarvestPlus program provided the financial support and there is no conflict of interest.

\section{References}

1. Hambridge M. Human zinc deficiency. J Nutr 2000; 130: $1344-9$.

2. Lira PI, Ashworth A, Morris SS. Effect of zinc supplementation on themorbidity, immune function, and growth of low-birth-weight, full-term infants in northeastern Brazil. Am J Clin Nutr 1998; 68: 418S-24S

3. Yip R. Iron deficiency: contemporary scientific issues and international programmatic approaches. J Nutr 1994; 124: 1479S-90S

4. Holtz C, Brown KH. Assessment of the risk of zinc deficiency in populations and options for its control. Food Nutr Bull 2004; 25: S91-204.

5. McGuire J. Addressing micronutrient malnutrition. SCN News 1993; 9: 1-10.

6. Iqbal A, Khalil IA, Ateeq N, Khan MS. Nutritional quality of important food legumes. Food Chem 2006; 97: 331-5.

7. Freire WB. Strategies of the Pan American Health Organization/World Health Organization for the control of iron deficiency in Latin America. Nutr Rev 1997; 55: 183-8.

8. Costa GEA, Queiroz-Monici KS, Reis SMPM, Oliveira AC. Chemical composition, dietary fiber and resistant starch contents of raw and cooked pea, common bean, chickpea and lentil legumes. Food Chem 2006; 94: 327-30.

9. Welch RM, Graham RD. Breeding crops for enhanced micronutrient content. Plant Soil 2002; 245: 205-14.

10. Souza SB, Szarfac SC, Souza JMP. Práctica de alimentación en el primer año de vida en niños que asisten a los servicios de salud escolar en São Paulo. Rev Nutr 1999; 12: 167-74.

11. Marchioni DML, Latorre MRDO, Szarfac SC, Souza SB. Complementary feeding: study on prevalence of food intake in two health centers of São Paulo city. Arch Latin Am Nut 2001; 51: 161-6.

12. Sichieri R, Castro JFG, Moura AS. Factors associated with dietary patterns in the urban Brazilian population (In Spanish). Cadernos de Saúde Pública 2003; 19: 47-53.

13. Association of Official Analytical Chemists (AOAC). Method 990.08; 9.2.39. Mineralization (HNO3:HClO4). Official Methods of Analysis of AOAC International. 18th ed. Gaithersburg, MD: AOAC International, 2005a. 
14. Association of Official Analytical Chemists (AOAC). Method 990.08; 9.2.39, p. 46. Minerals quantification (ICP) - Official Methods of Analysis of AOAC International. 18th ed. Gaithersburg, MD: AOAC International, 2005b.

15. Analytical Procedures of the Instituto Adolfo Lutz. Procedimientos Analíticos de lo Instituto Adolfo Lutz. 3rd ed., São Paulo, Brazil, 1985.

16. Coelho CMM, Bordin LC, Souza CA, Miquelluti DJ, Guidolin AF. Cooking time of beans according with the type of water. Ciênc Agrotec Lavras 2009; 33(2): 560-6.

17. Ribeiro ND, Jost E, Cerutti T, Mazieiro SM, Poersch NL. Composition of microminerals in common bean cultivars and applications for genetic improvement (In Spanish). Bragantia 2008; 67: 267-73.

18. Beebe S, Gonzalez AV, Rengifo J. Research on trace minerals in the common bean. Food Nutr Bull 2000; 21: 387-91.

19. Sripriya G, Antony U, Chandra TS. Changes in carbohydrate, free amino acids, organic acids, phytate and $\mathrm{HCl}$ extractability of minerals during germination and fermentation of finger millet (Eleusine coracan). Food Chem 1997; 58: 345-50.

20. Brazilian Food Composition Table/NEPA-UNICAMP.T113 Version II. - 2nd ed. - Campinas): NEPA-UNICAMP, 2006. $113 \mathrm{p}$.

21. Ramírez-Cárdenas L, Leonel AJ, Costa NMB. Effect of domestic processing on the nutrients content and in the antinutritional factors of different cultivars of common beans (In Spanish). Ciênc Tecnol Aliment 2008; 28: 200-13.
22. Codex Alimentarius Commission. Guidelines for use of nutrition claims. Rome: FAO, 1997. [Joint FAO/WHO Food Standards Program, CAC/GL 23-1997; revised 2004.]

23. Mechi R, Caniatti-Brazaca SG, Arthur V. Chemical evaluation, nutritional and antinutritional factors of irradiated black beans (Phaseolus vulgaris L.). Ciênc Tecnol Aliment 2005; 25: 109-14.

24. United States Department of Agriculture (USDA) - Food and Nutrition Information Center. http://www.nal.usda.gov/ fnic [cited 2011].

25. Food and Agriculture Organization/FAO/Latinfoods. http:// www.rlc.fao.org/foro/latinfoods/ [cited 24 January 2012].

26. Hemalatha S, Platel K, Krishnapura S. Influence of heat processing on the bioaccessibility of zinc and iron from cereals and pulses consumed in India. J Trace Elem Med Bio 2007; 21: $1-7$.

*Lucia M. J. Carvalho

Rio de Janeiro Federal University

CCS, Pharmacy College

Av. Carlos Chagas Filho, 373, bl. L, lab. 17

21941.590 Rio de Janeiro, Brazil

Tel: +55 (2I) 22609192 or 22801784 ext. 250; +55 (2I) 2572।I 63

Email: luciajaeger@gmail.com 